\title{
Improving Literacy Skills of Students with Different Learning Styles Using E-6tslearning
}

\author{
Pradnya Permanasari*, Ida Ayu Panuntun, Rizka Hayati \\ Program Studi Pendidikan Bahasa Ingris, Universitas Pekalongan, Indonesia \\ *pradnyaronita@gmail.com, ayyu-idda@yahoo.com,rizkalinguistik@gmail.com
}

DOI: $10.20884 / 1 . j 11.2021 .12 .2 .2663$

\begin{abstract}
Article History:
First Received:

ABSTRACT

$05 / 11 / 2020$

Final Revision:

This research was aimed at describing what learning styles dominate the students' reading and writing abilities and how E-6tslearning improve the the fourth semester students' reading and writing skills of the English Language

$20 / 12 / 2021$ Education Study Program of Teacher Training and Education Faculty of Pekalongan University. The writer used classroom action research (CAR) with

Available online: 28 students as samples. The writer used planning, acting, observing and

$31 / 12 / 2021$ reflecting cycles. The writer used questionnaires to determine students' learning styles and their satisfaction with the use of E-6tslearning and tests to measure their reading and writing skills. The results of the questionnaire analysis showed that there were three learning styles; those were visual, auditory and kinesthetic. From the results of the comparison of pre-test and post-test, students with kinesthetic learning styles experienced the best improvement of all, the visual group was the second one and the auditory group got the lowest achievement. The results of the pre-test and post-test comparison show an improvement in students' skills and motivation. This proves that the use of e-6tslearning can improve students' reading and writing skills. The results of the questionnaire analysis of student satisfaction on the use of e-6tslearning shows that learning by using e-6tslearning, students can improve their reading and writing skills and digital literacy. They can learn with fun with and without lecturer's assistance.
\end{abstract}

Keywords: reading; writing; digital literacy; learning styles

\section{INTRODUCTION}

English as an international language will definitely be used in the use of modern technology. A variety of modern technologies are also used in supporting learning English. This phenomenon has not yet occurred in the teaching and learning process at Pekalongan University. Many teaching and learning process is still done traditionally in class using lecturing and discussion techniques. The lecturers have not applied the technology well. Only a few lecturers do the learning process using online strategies. It makes the students get bored in the process of 
learning English. Teaching learning process should not only increase students' knowledge but also must develop their creativity, critical thinking, and characters such as social skills, tolerance, productivity, and adaptive skills (Narmaditya, Winarning, Wulandari, 2017). Teaching English is crucial for communicative purpose to cope with the growth of demand for English, both in national or international (Hosaain, 2015).

As a good method in learning, the teachers should use media in their teaching. Sudiran and Prasetiyowati (2014) state that media is essential to teaching learning process. According to Chandra \& \& Lloyd (2008), the role of electronic media on the language learning, learners' further involvement in their learning and the assessment. In addition, Gilbert, Morton \& Rowley (2007), it was strongly recommended that 'technology-mediation yields better learner's achievement. Moreover, Liu \& Chu (2010) state self-created strategies like instructional ones ought to empower understudies to assume responsibility they could call their own learning and lead to autonomy, independence and achievement. E-learning is information and communication technology to activate students to learn anywhere and everywhere (Hartanto, 2016). Using multimedia tools, an online English class can have video, audio, images and interactive exercises that facilitate the student's experience and transform the moment of learning in a fun and light practice (Barbarick, 2010). Based on those statements above, it can be concluded that the role of electronic media is important to support the teaching learning of English.

Lack of students' motivation is one of the problems in learning English. This can be caused by the way the lecturer teaches or the teaching method used by the lecturer. For teachers, knowledge about students' motivational beliefs will help teacher to create learning environment that will be well suited for students' psychological needs (Boekaets, 2016). Motivation is fundamental element of students learning, and teachers can assist students to increase and develop students' motivation to get optimal achievement in the classroom (Valerio, 2012) Students will get bored easily every time a lecturer teaches them using the traditional or conventional way. At present, students are not passive agents in the learning process, they become active agents. An interesting teaching and learning process must involve students as the center of learning. Some interesting methods, strategies, and media can be used to help them become interested in the learning process, especially the process of learning to read and write.

The lecturer plays an important role to make the teaching and learning process successful by having four lecturer competencies: pedagogical, professional, social and personality. In the teaching process, lecturers can apply their pedagogical competencies using learning methods and media. Learning methods and media can help students master the material easier. In this global and modern era, lecturers are not only expected to have good literacy skills in several ways, but 
also must be able to make students have good literacy skills. Literacy skills empower people with the critical skills which will help them to be independent learner (Ranaweera, 2008). Moreover, literacy skills were taught to use assertiveness and internet technologies to engage in self-study of their class materials or for personal interest (Silver, 2008).

These skills will enable people to Students in this case, are also expected to master digital literacy. The author will focus literacy discussions on students' ability to read and write for academic purposes. In reading there must be a process called understanding; it is the purpose of reading that students must master text content (Rosari \& Mujiyanto, 2016). In fact, the ability to use language communicatively does not only use one skill. Susan, et.al (2020) state that reading is considered an important skill that influences other language skills.

One important component that influences the teaching and learning process is students' learning styles. Learning styles is particular significance in promoting teaching and learning experiences (Jaleel \& Thomas, 2019). Learning styles show the individual differences of students in learning that play an important role in the teaching and learning process. Lecturers must be able to know the learning styles of their students. By knowing it, lecturers can prepare themselves in teaching and developing students' English performance (Manikowati \& Bharati, 2017). How lecturers integrate all learning styles is still a big question. Wong and Nunan (2014) state the distinctions between active and passive students in terms of learning styles, strategies and practices. Students can learn using their own learning styles. Those can be concluded that by applying learning styles, strategies and practices, the effective students will be more having a good confidence in communicating of learning English.

The novelty of this research is the integration and modification of literacy teaching strategies which are the use of 6TS (Time, Text, Teach, Talk, Task, Test, and Summary) made by Richard Allington in teaching Digital Literacy at the university level with the use of digital media namely E-Learning. The integration and modification of literacy teaching strategies and digital media are moderated by student learning styles.

\section{MATERIALS AND METHOD}

The writer uses classroom action research (CAR) in this study. The purpose of classroom action research is to change the teaching behavior of lecturers, the behavior of students in the classroom, improve the learning practices, and change the framework of implementing classroom learning taught by the lecturer so that there is an increase in teacher professional services in managing the learning process. 
According to Hopkins (1993), classroom action research begins with planning actions, implementing actions, observing and reflecting the process and results of actions (observation and evaluation). While the procedure in class action research consists of four components; namely planning (planning), implementation (acting), observation (observing), and reflection (reflecting). The steps of classroom action research are as follows:

Figure 1. Action Research Design

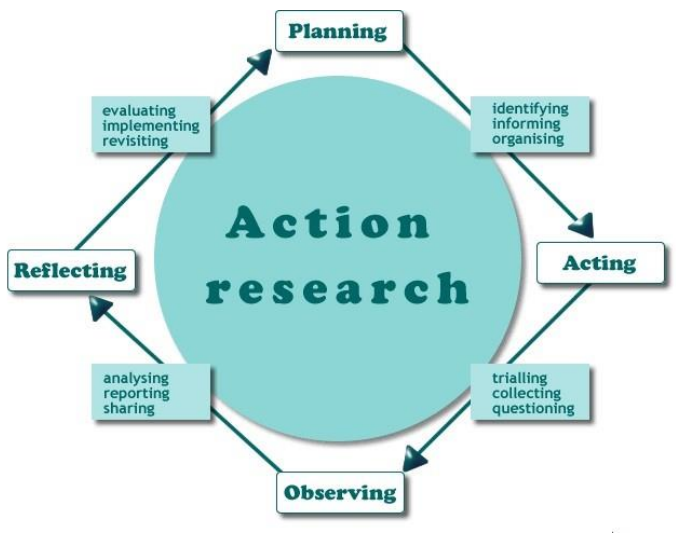

The subjects of this study were the fourth semester students of the English Language Education Study Program Faculty of Teacher Training and Education (FKIP), Pekalongan University. The population of this study was all semester 4 students of the English Education Study Program FKIP Pekalongan University, as many as 57 students. The writer only took 28 morning class students as the research samples.

The procedure of the study was started from planning, that is the preparation made by the writer in carrying out classroom action research which includes activities: compiling learning plans and making learning media. The second is acting, a description of the action taken, the corrective action and the procedure of action to be carried out by the writer. The next is observing, conducted to see the implementation of previous actions that have been made well, ensuring there are no deviations that can provide results in improving student learning outcomes. The last step is reflecting, evaluation activities as a result of actions that have been implemented. At this step the changes will occur. How and to what extent the actions determined are able to achieve change or resolve the problem significantly. From this reflection activity, the writer can decide the next step that can be taken to achieve the expected improvement.

The writer used some methods to collect the data. The first, the writer provided a questionnaire instrument during the observation phase in class. This questionnaire was given twice, namely a questionnaire about students' learning styles and a questionnaire of students' 
satisfaction in using E-6 Learning. The second, the writer used test. The test was carried out to measure the students' ability in reading and writing. Test is in the form of instructions for reading and writing. The writer provided two types of tests, namely pre-test to measure the students' basic abilities of reading and writing and post-test to measure the improvement in students' reading and writing abilities by using E-6 Learning.

The writer used two techniques of data analysis; they are questionnaire analysis and test analysis. The writer used qualitative data analysis to analyze the students' questionnaire. The writer described the results of the observation checklist, classified the problems and shortcomings faced, interpreted the data, and finally made conclusions and came up with a solution. The writer analyzed students' test results as a measurement tool for students' ability to read and write. The writer used reading and writing assessments with a range of values quantitatively in pre-test and post-test.

\section{RESULTS \& DISCUSSION}

\section{Students' Learning Styles Result}

The writer analyzed the results of students' learning styles questionnaires of semester 4 (four) English Education Study Programs at Pekalongan University in the academic year $2019 / 2020$.

Table 1. Students' Learning Styles Result

\begin{tabular}{|c|c|c|c|c|}
\hline \multirow{2}{*}{ No } & \multirow{2}{*}{ Students' Codes } & \multicolumn{3}{|c|}{ Students' Learning Styles } \\
\hline & & Visual & Auditory & Kinesthetic \\
\hline 1 & $\mathrm{~S} 1$ & $\checkmark$ & & \\
\hline 2 & $\mathrm{~S} 2$ & $\checkmark$ & & \\
\hline 3 & S3 & & & $\checkmark$ \\
\hline 4 & $\mathrm{~S} 4$ & & $\checkmark$ & \\
\hline 5 & S5 & & & $\checkmark$ \\
\hline 6 & S6 & $\checkmark$ & & \\
\hline 7 & S7 & & $\checkmark$ & \\
\hline 8 & S8 & $\checkmark$ & & \\
\hline 9 & S9 & & & $\checkmark$ \\
\hline 10 & S10 & & $\checkmark$ & \\
\hline 11 & S11 & & & $\checkmark$ \\
\hline 12 & S12 & & $\checkmark$ & \\
\hline 13 & S13 & $\checkmark$ & & \\
\hline
\end{tabular}




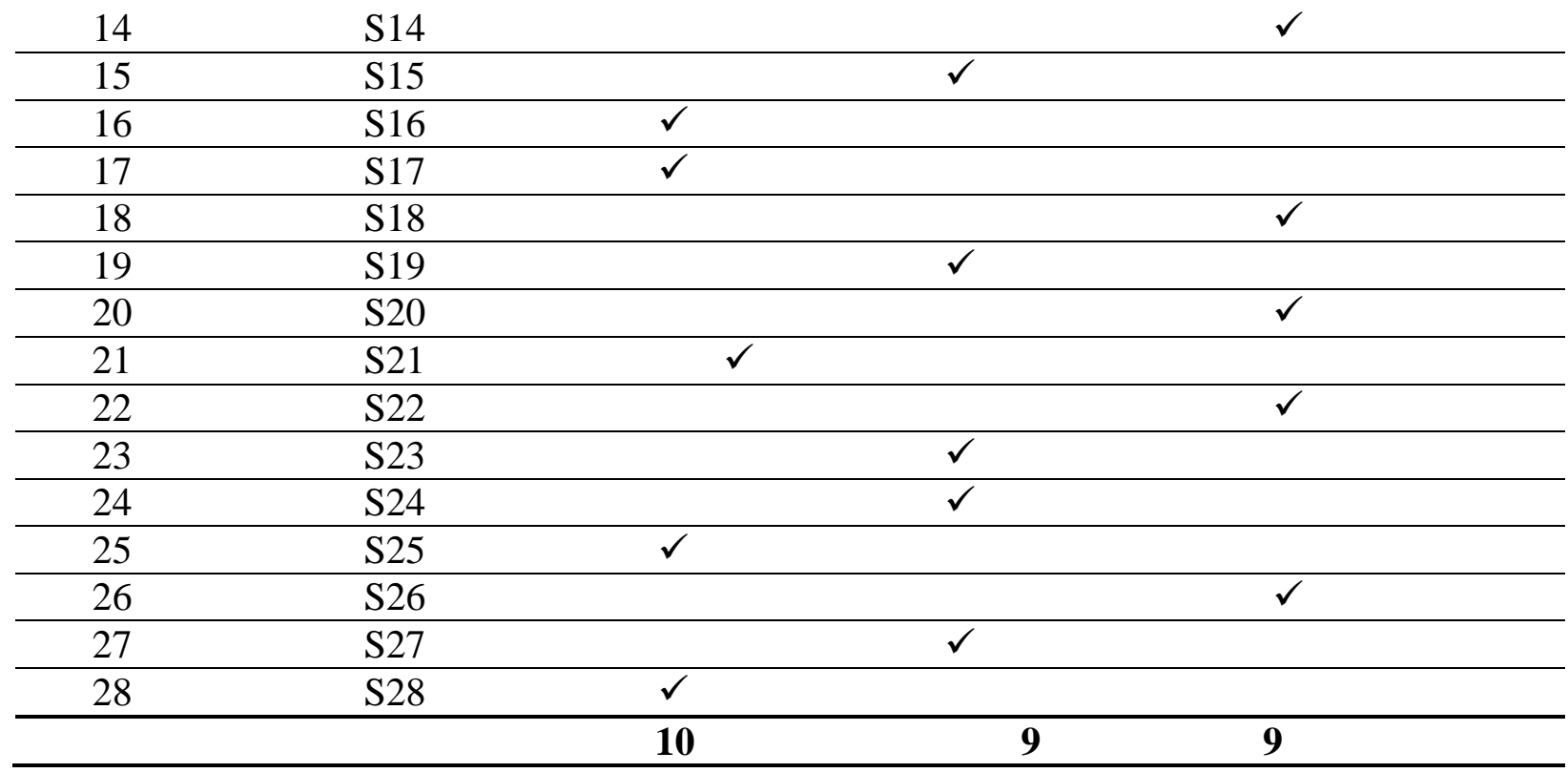

The table shows students' learning styles. From this table it can be concluded that the 4th semester students have all learning styles namely visual, auditory, and kinesthetic. The number of student comparisons with their learning styles is almost the same, 10 for visuals, 9 for auditory, and 9 for kinesthetic. The highest number of students is students with a visual learning style with 10 points, followed by an auditory and 9 points each.

From these results, the number of students with the highest learning styles is visual. This indicates that the learning styles of students who use visual media are quite high. The conclusion is the learning process must consider visual methods such as the use of material in power points, the provision of books, teaching materials, and modules.

Auditory and kinesthetic learning styles have the same number of students, which are 9 students. It can be concluded that in addition to the use of visual methods, the methods that use auditory methods such as the use of video, music, direct explanation by lecturers are also quite important to use. Likewise, with the kinesthetic method, the use of learning methods that use the kinesthetic method also needs to be considered, such as writing an essay because it involves motor movements.

From the analysis of students' learning styles, it is necessary to think about a learning method that can accommodate all students' learning styles. In addition, the method must also consider the current style of students who are included in millennial era, where they have a high interaction with information technology. From this, the writer used the E-6tslearning application that can accommodate all learning styles, moreover learning using this application also heeded the principle of learning that is close to millennial students. 


\section{Students'Pre-Test Result}

Pre test needs to be done to find out the results of the initial ability scores of students. The pre test score also determines whether it is necessary to increase the students' score or not. The following are the results of the pre-test scores for each group of learning styles.

Table 2. Result of Students with Visual Learning Style

\begin{tabular}{ccccc} 
No & NPM & Students' Codes & Class & Score \\
\hline 1 & 918013171 & S1 & Class A & 87 \\
\hline 2 & 918012861 & S2 & Class A & 85 \\
\hline 3 & 918013181 & S6 & Class A & 75 \\
\hline 4 & 918013041 & S 8 & Class A & 81 \\
\hline 5 & 918013031 & S13 & Class A & 81 \\
\hline 6 & 918013001 & S16 & Class A & 76 \\
\hline 7 & 918012751 & S17 & Class A & 79 \\
\hline 8 & 918012851 & S21 & Class A & 75 \\
\hline 9 & 918012651 & S25 & Class A & 81 \\
\hline 10 & 918013061 & S28 & & 76 \\
\hline & & & & $\mathbf{7 9 6}$ \\
\hline
\end{tabular}

From the above table it can be concluded that the pre test results of students with the visual learning style of semester 4 indicate the number 79.6. This score is included in the Average category. Since the average grade of students with visual learning style was still included in the average category, it is necessary to improve the ability to achieve more satisfying grades.

Table 3. Result of Students with Auditory Learning Style

\begin{tabular}{ccccc} 
No & NPM & Students' Codes & Class & Score \\
\hline 1 & 918012901 & S4 & Class A & 80 \\
\hline 2 & 918012841 & S7 & Class A & 77 \\
\hline 3 & 918013021 & S10 & Class A & 79 \\
\hline 4 & 918013051 & S12 & Class A & 76 \\
\hline 5 & 918012921 & S15 & Class A & 81 \\
\hline 6 & 918013011 & S19 & Class A & 81 \\
\hline 7 & 918012661 & S23 & Class A & 85 \\
\hline 8 & 918012631 & S24 & Class A & 85 \\
\hline 9 & 918013081 & S27 & Class A & 76 \\
\hline & TOTAL & & & $\mathbf{7 2 0}$ \\
\hline & Average & & & $\mathbf{8 0}$ \\
\hline
\end{tabular}

Based on the table above, it can be seen that the score of students with auditory learning 
style was higher than students with visual learning style. The average of the auditory learning style students was 80 , and was included in the good category. Like the results of visual grades, the results of auditory students need to be improved.

Table 4. Result of Students with Kinesthetic Learning Style

\begin{tabular}{ccccc} 
NO & NPM & Students' Codes & Class & Score \\
\hline 1 & 918012641 & S3 & Class A & 89 \\
\hline 2 & 918012731 & S5 & Class A & 76 \\
\hline 3 & 918012831 & S9 & Class A & 79 \\
\hline 4 & 918012741 & S11 & Class A & 80 \\
\hline 5 & 918012871 & S14 & Class A & 76 \\
\hline 6 & 918012691 & S18 & Class A & 87 \\
\hline 7 & 918012811 & S20 & Class A & 79 \\
\hline 8 & 918012761 & S22 & Class A & 76 \\
\hline 9 & 918013091 & S26 & Class A & 85 \\
\hline TOTAL & & & $\mathbf{7 2 7}$ \\
\hline Average & & & $\mathbf{8 0 . 7 8}$ \\
\hline
\end{tabular}

The average of the pre test of students with kinesthetic learning styles was 80.78 . It was the highest pre-test scores of other learning styles. It can be said that the students with kinesthetic learning styles got the highest scores of all.

\section{Students' Post Test Result}

Based on the results of the post-test held on March 25, 2020, to 28 morning class students as the research samples, the results were obtained as attached in the tables below. Post test was carried out to all students. The scores in each table are as follows:

Table 5. Result of Students with Visual Learning Style

\begin{tabular}{ccccc} 
No & NPM & Students' Codes & Class & Score \\
\hline 1 & 918013171 & S1 & Class A & 91 \\
\hline 2 & 918012861 & S2 & Class A & 89 \\
\hline 3 & 918013181 & S6 & Class A & 83 \\
\hline 4 & 918013041 & S8 & Class A & 83 \\
\hline 5 & 918013031 & S13 & Class A & 85 \\
\hline 6 & 918013001 & S16 & Class A & 81 \\
\hline 7 & 918012751 & S17 & Class A & 82 \\
\hline 8 & 918012851 & S21 & Class A & 79 \\
\hline 9 & 918012651 & S25 & Class A & 82 \\
\hline 10 & 918013061 & S28 & Class A & 78 \\
\hline & & & & $\mathbf{8 3 3}$ \\
\hline & TOTAL & & $\mathbf{8 3 . 3}$ \\
\hline
\end{tabular}


The post test was carried out after the students were given treatment for 2 weeks using the online learning method, namely e-6 learning application. The application provides the students features that have been adapted to the stages of manual learning. The table shows that the post test average score in the visual learning style is 83.3. An average score of 83.3 indicates that the ability of students is in the very good criteria. Very good category means that students have been able to make a summary which contains elements of information taken from several sources clearly. The summary has a writing organization that has few errors.

From that explanation, it can be concluded that the use of e-6tslearning application provides attractive displays that is able to attract students to be more involved in learning. The next is the result of post test of students with auditory learning style.

Table 6. Result of Students with Auditory Learning Style

\begin{tabular}{|c|c|c|c|c|}
\hline No & NPM & Students' Codes & Class & Score \\
\hline 1 & 918012901 & S4 & Class A & 82 \\
\hline 2 & 918012841 & S7 & Class A & 79 \\
\hline 3 & 918013021 & S10 & Class A & 79 \\
\hline 4 & 918013051 & S12 & Class A & 78 \\
\hline 5 & 918012921 & S15 & Class A & 84 \\
\hline 6 & 918013011 & S19 & Class A & 85 \\
\hline 7 & 918012661 & $\mathrm{~S} 23$ & Class A & 85 \\
\hline 8 & 918012631 & S24 & Class A & 83 \\
\hline 9 & 918013081 & $\mathrm{~S} 27$ & Class A & 79 \\
\hline \multicolumn{4}{|c|}{ TOTAL } & 734 \\
\hline \multicolumn{4}{|c|}{ Average } & 81.55 \\
\hline
\end{tabular}

The table shows the students with auditory learning style post test scores. From the table, it is known that the average score of students' abilities in the auditory learning style is 81.55 . An average score of 81.55 based on the student's ability criteria indicates very good criteria. Very good category in the students with auditory learning style indicates that the e-6-learning application has been equipped with a combination of various abilities that can explore the students' potential, so that the students will be more interested in learning with the help of this media. The next is the result of students with kinesthetic learning style post test. 
Table 7. Result of Students with Kinesthetic Learning Style

\begin{tabular}{ccccc} 
No & NPM & Students' Codes & Class & Scores \\
\hline 1 & 918012641 & S3 & Class A & 91 \\
\hline 2 & 918012731 & S5 & Class A & 83 \\
\hline 3 & 918012831 & S9 & Class A & 82 \\
\hline 4 & 918012741 & S11 & Class A & 83 \\
\hline 5 & 918012871 & S14 & Class A & 85 \\
\hline 6 & 918012691 & S18 & Class A & 93 \\
\hline 7 & 918012811 & S20 & Class A & 82 \\
\hline 8 & 918012761 & S22 & Class A & 83 \\
\hline 9 & 918013091 & S26 & Class A & 88 \\
\hline & TOTAL & & & $\mathbf{7 7 0}$ \\
\hline & Average & & & $\mathbf{8 5 . 5 5}$ \\
\hline
\end{tabular}

The table shows the result of the students with kinesthetic learning style test post. The average of students' post test is 85.55. The average score indicates that the ability of students in this learning style is very high in other words the ability is ranked Excellent. The Excellent predicate is the highest criterion in the students' ability. Excellent means that most students have been able to make a summary that contains all elements of information that are presented clearly; there were no language errors and the information is fast and easy to understand.

\section{DISCUSSION}

\section{Planning}

The first stage of the CAR is the planning stage. The planning stage begins with evaluating the results of the pre-test and the conservation of the learning styles of the students. The pre-test was conducted on 4 March 2020. The pre-test results showed that the students' scores in writing material were still in the average or average category. Therefore, it is necessary to increase the students' ability in reading and writing, especially in Digital Literacy courses. Another reason for improvement is to see the importance of reading and writing skills in Digital Literacy courses. In Digital Literacy, writing and reading skills are very necessary because these skills are basic skills that can be used both for making digital-based teaching materials and in understanding information.

Planning is also based on students' learning styles analysis. Analyzing students' learning styles is important because learning styles determine the appropriate learning methods used for students. From the results of students' learning styles analysis, there are 3 learning styles used by students, namely visual, auditory, and kinesthetic. From the results of the analysis, the writer must determine a method that can accommodate these three learning styles. 
From the results of the pre-test and observation analysis, the writer determined the things that need to be integrated in the lesson plan and syllabus so that the lesson plan and syllabus have strong planning and can properly increase students' abilities and skills in reading and writing. The writer used E-6tslearning as a learning method.

\section{Acting}

After the planning stage is carried out, the next stage is the acting or implementation stage. In implementation, the writer conducted activities that have been planned in the lesson plan and syllabus, namely improving students' skills by using the E-6tslearning application. The learning process using the E-6TS method was conducted on March 18, 2020. The following are the stages of learning using the E-6tslearning method.

a. Time

Lecturer gave students time to read some texts that must be sought and obtained through internet sources. The lecturer gave a time that was in accordance with the amount of text that students must read.

b. Text

Lecturer provided several texts for students to read. This text is based on the student's level. It can be given every day to make students understand a lot of reading texts.

c. Teach

An important part of teaching is to provide appropriate allocation of time and teaching material. Yet in this method, active instruction such as lecturer modeling and demonstration becomes an important role to get a good reader. Lecturers in this step must provide models and demonstrations on how to read and write well so that students will imitate and become literate. The lecturer also must give some materials to support the students to understand some information that are taken from internet sources.

d. Talk

Lecturers and students discussed ideas, concepts, hypotheses, strategies, and responses with others. The questions asked by the lecturer were more "open" questions, where several responses will be appropriate.

e. Task

Lecturers gave students more assignments to measure students' understanding. They read entire books, complete individual and small group research projects, and work on assignments that integrate multiple fields of content (reading, writing, and social studies). 


\section{f. Test}

This is the time for the lecturer to evaluate the students' literacy. This means that lecturers provided tests and individual measurements so that different achievement between students will be seen. Lecturer can decide which students are better at reading and writing.

\section{g. Summary}

The final step is to make a summary. The lecturer asked students to make a summary of books and reading resources from the internet owned by students.

\section{Observing}

Observing phase (observation) is the stage where the observation of learning treatment using the e-6tslearning application is carried out. The observation was carried out during the learning process. Based on observations, the writer saw that the class conditions were very conducive. This is an evident of the students' enthusiasm in joining the learning actively. The involvement of these students was influenced by the supporting factors of learning in the form of media that tried to unite several aspects needed in improving the ability to learn English in one neatly arranged component. The use of the media helps the lecturer and students in communication.

\section{Reflecting}

In the reflection phase, the writer conducted an evaluation to decide whether the use of e6tslearning can be used to improve Digital Literacy learning. As a measuring tool to determine the students' ability, at the final stage the writer gave a post test to all samples.

The next one is the discussion of the results of a questionnaire analysis provided by writer to students about their satisfaction in using the e-6tslearning application as an online learning method, it is known that:

1. All students state that e-6tslearning gives students the freedom to study independently.

2. One student states that e-6tslearning provides students with a time limit for learning.

3. All students state that by using e-6tslearning students get improved skills in using digital technology.

4. All students say that e-6tslearning makes students able to learn independently even without lecturer's assistance.

5. Two students state that e-6tslearning has prevented students from learning organization.

6. All students declare e-6tslearning provides an opportunity for all students who have different learning styles to participate in learning well and fun. 
7. All students state that e-6tslearning provides their learning more effective than manual learning.

Based on the results of the discussion of the test scores previously, it can be seen that through comparisons on the pre-test and post-test scores, there will be a very significant increase in Digital Literacy learning after using e-6tslearning. The comparison of these scoresappears in the following table.

Table 8. Comparison of Students' Pre-Test and Post-Test Scores

\begin{tabular}{cccc} 
Gaya Belajar & Pre-Test & Post-Test & Rata-Rata \\
\hline Auditory & 80 & 81.55 & 80.775 \\
\hline Visual & 79.6 & 83.3 & 81.45 \\
\hline Kinestetik & 80.77 & 85.55 & 83.16 \\
\hline
\end{tabular}

The table shows the comparison of the students' pre-test and post-test scores in which each learning style has an improvement. In the auditory learning style the pre-test score is 80 , while the post test is 81.55 . The next result is visual learning style. The pre-test score in this learning style is 79.6 and the post-test score is 83.3. The final result is a comparison of scores on kinesthetic learning styles. The pre-test score on kinesthetic is 80.77 and post-test is 85.55 . In other words, the apparent improvement in each learning style is the evidence that the use of the e-6tslearning teaching method can be used to improve students' learning abilities in learning Digital Literacy.

\section{CONCLUSION}

This research was conducted to answer two big questions, namely what learning styles dominate the Digital Literacy learning and how the use of e-6tslearning can improve students' ability in reading and writing at Pekalongan University. The results of the questionnaire analysis showed that the learning style that dominated was visual learning style with 10 students. Learning styles in the second and third order are auditory and kinesthetic. Therefore, the writer must consider learning methods that accommodate these three learning styles. In this research, the writer used the E-6tslearning application.

In the auditory learning style the pre test score is 80 , while the post test is 81.55 . The next result is visual learning style. The pre-test score in this learning style is 79.6 and the post-test score is 83.3. The next comparison is in the kinesthetic learning styles. The pre-test score on kinesthetic is 80.77 and post-test is 85.55 . In other words, the apparent improvement in each learning style 
becomes the evidence that the use of the e-6tslearning method can be used to improve students' learning abilities in learning Digital Literacy

\section{REFERENCES}

Barbarick, K. A. (2010). Crossword Puzzles as Learning Tools in Introductory Soil Science. Journal of Natural Resources and Life Sciences Education, 39: 1: 145-149.

Boekaerts, M. (2016). Motivation to Learn. International Academy of Education. Retrieved from http://www.curtin.edu.au/curtin/dept/smec/iae.

Chandra, V., \& Lloyd, M. (2008). The Methodological Nettle: ICT and Students' Achievement. British Journal of Educational Technology, 39(6), 1087-1098.

Hopkins, D. (1993). A Teacher's Guide to Classroom Research. Philadelphia. Open University Press.

Gilbert, J., Morton, S., \& Rowley, J.(2007). Learning: The Students' Experience. British Journal of Educational Technology, 38(4), 560-573.

Hartanto, W. (2016). Penggunaan E-Learning Sebagai Media Pembelajaran. Jurnal Pendidikan $\begin{array}{llllll}\text { Ekonomi. } & \text { Volume } & 10 & \text { No } & \text { (1). } & \text { Retrieved from }\end{array}$ https://jurnal.unej.ac.id/index.php/JPE/article/view/3438.

Hossain, M. I. (2015). Teaching Productive Skills to the Students: A Secondary Level Scenario. Department of English and Humanities: BRAC UNIVERSITY. Retrieved from https://core.ac.uk/download/pdf/74352632.pdf.

Liu, T. Y. \& Chu, Y. L. (2010). Using Ubiquitous Game in an English Listening and Speaking Course: Impact on Learning Outcomes and Motivation. Computers \& Education, 55, 630-64.

Manikowati \& Bharati, D. A. L. (2017). The Effectiveness of Multimedia in Teaching Writing to Students with Different Learning Styles. English Education Journal 7 (2), 85-91. Retrieved from http://journal.unnes.ac.id/sju/index.php/eej.

Narmaditya, B. S, Winarning., Wulandari, D. (2017). Impact of Problem-Based Learning on Students' Achievement in Economics Course. Classroom Action Research Journal. Volume 1 (1). Retrieved from http://journal2.um.ac.id/index.php/carjo.

Pacuilla, H. S. (2008). Investigating the Language and Literacy Skills Required for Independent Online Learning. Maryland : The International Institute for Literacy.

Ranaweera, P. (2008) Importance of Information Literacy Skills for an Information Literate. NACLIS. Retrieved from http://eprints.rclis.org/11956/.

Rosari, L., \& Mujiyanto, J. (2016). The Effectiveness of Know-What - Learned and Collaborative Strategic Reading Strategies to Teach Reading Comprehension to Students with Positive and Negative Attitude. English Education Journal.6 (2). Retrieved from http://journal.unnes.ac.id/sju/index.php/eej. 
Susan, S., Warsono, W., Faridi, A. (2020). The Evaluation of Exercises Compatibility Between Revised Bloom's Taxonomy and 2013 Curriculum Reflected in English Textbook. English Education Journal 6 (1). Retrieved from http://journal.unnes.ac.id/sju/index.php/eej.

Sudiran \& Prasetiyowati, E. (2014). The Implementation of Media in Teaching English for Young Learners (EYL). Celtic Journal, 1 (1), 1-15.

Valerio, K. (2012). Intrinsic Motivation in the Classroom. Journal of Student Engagement: Education Matters. Volume 2, Issue 1, article 6. Retrieved from https://ro.uow.edu.au/jseem/vol2/iss1/6/.

Wong, L. C., \& Nunan, D. (2011). The Learning Styles and Strategies of Effective Language Learners. Journal System, 39, 144-163. 